\title{
Artist Biographies
}

Fabian Anthony Barraza is an emerging artist and writer inspired by his family, fashion, contemporary art and his Indigenous South American (Mapuche) heritage. He began his creative career at the Footscray Community Arts Centre, participating in group shows such as Re/Semblance in 2005. Fabian is currently completing a BA in Professional Writing and Spanish at Victoria University. His visual and written works have been published in Seed.

JoEL BIRnie has exhibited extensively throughout Australia, beginning with a solo exhibition of ground sandstone works at the National Aboriginal Cultural Institute - Tandanya in January 2001. He of mixed heritage and belongs to the Pakana/Pinterrairer group of North and South East Tasmania. Joel's Indigenous works were extensively exhibited from 2001-04, with a second solo exhibition at NACI- Tandanya in 2003 and the collective exhibition Native Title Business, which toured nationally from 2002-05. Since 2004, Joel has taken up photography and short performance films as a way of making his work more portable.

Salvatore Celiento is a counselling lecturer and educates highschool boys regarding sexual assault. He is completing a Master of Counselling at Victoria University. Salvatore's paintings were published in Offset No. 8. He studies nine ryūha of classical Japanese martial arts.

Greg Humble is currently completing his final year of a BFA (Sculpture) at the VCA. As a result of winning two awards including Best Sculpture at the 2009 VCASU Proud exhibition, Greg will be exhibiting work at Off the Kerb Gallery in their 2010 calendar program. 
VANESSA KiELY has loved drawing and painting since being a young child and has always had a lot of encouragement off her parents to push her ability to a greater standard. Vanessa loves life drawing because she feels that one can really capture the mood of the model with the simple use of line and colour. Vanessa is a first year education student hoping to teach art to secondary school students.

Ellie June King studies Illustration at Chisholm in Frankston. At home, she tattoos her friends, using a tattoo gun she was given for her seventeenth birthday. Her favourite part of drawing is typography; she likes writing swear words in her sketch books to make her teachers feel awkward. Check out her blog at rittle-king. blogspot.com

From a young age, artist Phoebe Lyons was armed with a texta in one hand, paintbrush in the other; growing into a passionate dreamer with a thirst for the creative side; a wacky personality and imagination always there to fuel her. Completing a Visual Arts course in 2006, Phoebe now resides and works from her coastal studio in East Gippsland.

Elizabeth Palumbo is a Victoria University student, currently completing her third year of a Bachelor of Education. Elizabeth explores identity and heritage, drawing inspiration from family and life experiences. Elizabeth is a self-proclaimed 'procedural artist'; placing emphasis on experimentation which helps her to arrive at a final piece. Elizabeth favours working with ink and acrylic paints to create flat and bold pop art inspired pieces, with strong attention to detail.

Since he can remember, GARY PARKer has always had a passion for art. He studied Graphic Design/Fine Arts in between travel, which has also become a life passion he hopes to continue. Since 
graduating he has done numerous things that have lead to where he is now; designing t-shirts for Quiksilver.

Kate Schmutter has been attending the Gould Art School in Frankston for the past 2 years. Her chosen medium is oil on canvas with a realist style. Kate aspires to be accepted into the VCA next year. She is also interested in photography and drawing.

LENNI SCHUlz is a fifteen-year-old aspiring photographer from North Carolina USA. In her spare time she takes care of ten foster kittens that live in her room, and lurks around DeviantART.com

Michael Weldon was born in Manchester, England and emigrated to Australia, with his family, at the age of twelve. He developed a strong love of comics at an early age and this led him to an interest in drawing.

He studied graphic design at Victoria College in Melbourne, and after graduating spent four unfulfilling years in graphic design and advertising, before deciding to give it up to follow his passion for illustration.

Michael's work has appeared in numerous magazines including The New Yorker, Time, Rolling Stone, San Francisco Magazine, Seattle Metropolitan, Disney Magazine and The Big Issue. He has also designed several book covers.

He is currently working on ideas for his first graphic novel, but is finding it a difficult process.

Michael lives in Melbourne, Australia with his wife and cat. They are eagerly awaiting the birth of their first child. 